\title{
INVASION OF RARE WEED SPECIES AND ITS IMPACT ON NATURAL BIODIVERSITY
}

\section{Shuvar I. A., Korpita H. M.}

\section{INTRODUCTION}

The problem of weed control has been with mankind since the beginning of agricultural development. It is extremely important and includes both the practical aspect (prevention of «migration» of weeds to new areas, control of the most common and vicious weeds, including the use of herbicides, biological control methods) and theoretical (study of resettlement and reproduction of weeds, its viability and evolution). Weeds began to evolve not only under the influence of natural factors, but also under human activity, especially with the introduction of herbicides, which became the most powerful factor in the evolution of segetal vegetation ${ }^{1}$.

Weeds are an ecological group of plants formed as a result of their growth together with cultivated plants in the process of continuous control. As highly organized plants, they have high ecological plasticity. Adapting to the living conditions of cultivated plants, weeds acquire similar properties. On agricultural lands, cultivated plants and weeds grow together and form agrophytocenoses, in which, due to the exceptional viability of weeds, their stability in competition is preserved $^{2,3}$.

Equally acute is the problem of invasion of rare weeds, ie those that have not previously been found in the ecosystem and threaten the functioning of natural biodiversity. Scientists recorded a mass invasion of alien plant species in Eastern Europe several decades ago, together with the intensification of economic activity on the planet and the

${ }^{1}$ Іващенко О.О. Бур'яни в агрофітоценозах. Київ, 2001. 236 с.

2 Шувар I.А., Корпіта Г.М. Особливості забур'янення агроценозів ячменю ярого і картоплі залежно від застосування гербіцидів. ScienceRise, 2016. № 9(1). C. 39-43.

3 Шувар І.А. Екологічні основи зниження забур'яненості агрофітоценозів. 2008. $496 \mathrm{c}$. 
development of international trade. Global climate change is only accelerating this process.

When they appear in the new territory, invasive species show their rather aggressive features: they suppress the plants that originally grew, break the ties established in ecosystems for thousands of years and lead to floristic pollution of the territory, which impoverishes the aboriginal flora.

Harmfulness of invasive species is determined by the allergenicity of pollen from many of them (for example, all types of Ambrosia, Cyclachaena xanthiifolia, etc.), which poses a serious threat to public health. But these processes are complicated not only by environmental losses but also by economic ones ${ }^{4,5,6}$.

On the basis of researches of many experts the main reasons of strengthening of expansion of the invasive species characteristic of the modern life period are revealed:

- the presence of a large number of disturbed ecotopes, «open» to invasions;

- expansion of ties and their intensification between states and the development of transport links, which are a direct way of introducing atypical plant species;

- decline of agricultural production, which led to a decrease in the number of livestock, the formation of large areas of abandoned and neglected lands, which are a source of accumulation, reproduction and spread of nitrophilic ruderals;

- lack of natural enemies-phytophagous, which would neutralize their spread in the historical homeland;

- uncontrolled human introduction of new species, forms and varieties of wild plants contribute to successful invasions $7,8,9$.

4 Invasive aquatic species of Europe. Distribution, impacts and management (E.Leppakoski et. al. eds.). 2002. Netherlands : Kluwer Ac. Publ. 583 p.

Wratten S.D. Biological control: measures of success. Ed. G. Gurr, S.D. Wratten. Springer, 2002. 429 p.

6 The Problem With Invasive Plants. URL: https://www.portlandoregon.gov/ bes/article/330681

7 Шувар I.А., Гудзь В.П., Шувар А.І. Особливо небезпечні рослини України : навчальний посібник / за ред. І.А. Шувар. 2013. 192 с.

${ }^{8}$ Pheloung P.C., Williams P.A., Halloy S.R. A weed risk assessment mode for use as a biosecurity tool evaluating plant introductions. Journal of Environmental Management. 1999. Vol. 57. P. 239-251.

9 Invasive species. URL: http://stateoftheworldsplants.org/2017/report/ SOTWP_2017_9_invasive_species.pdf 


\section{Exacerbation of the problem of invasion and harmfulness of rare weeds for biodiversity}

The area of land that is not being developed by new landowners or is being released from intensive economic use and is being heavily weeded has increased 4.2-5.1 times in recent years. Annual potential reserves of weed seeds are replenished by 25-50 thousand units $/ \mathrm{m}^{2}$ and amount to 1.17-2.54 billion/ha in the arable soil layer. Even with the annual best implementation of a set of agronomic measures and the use of herbicides to reduce soil contamination to the initial level in such fields will last at least 30-40 years. Work related to their transformation into agricultural circulation requires significant production costs and causes an increase in environmental risk ${ }^{10}$.

One of the most acute problems of modern ecology is the settlement of species outside the natural range. The primary agent of their spread is man, consciously or subconsciously he transfers alien species from the diaspora outside their natural range. The dynamics of settlement may be different. The plant may not show obvious activity for a long period of time, and then - to settle quickly ${ }^{11,12}$.

Plant invasions are one of the root causes of modern evolution of phytocenoses. Alien elements of flora, transferred outside their natural range, penetrate into aboriginal groups and affect their dynamics and stability. Such acts lead to a change in the structure of phytocenoses due to the redistribution of econites, and to a change in the vector of succession, due to a violation of syngenesis.

Changes in the ecosystem caused by invasive species that are not important for human well-being usually do not attract much attention from the general public, although their impact may be very important for the ecosystem ${ }^{13,14}$

However, the impact of invasive species on the ecosystem, which also takes into account human interests, is attracting public attention around the world.

${ }^{10}$ Іващенко О.О. Бур'яни в агрофітоценозах. 2001. 236 с.

11 Шувар I.А., Гудзь В. П., Шувар А.І. Особливо небезпечні рослини України : навчальний посібник / за ред. І.А. Шувар. 2013. 192 с.

12 nvasive weeds. URL: http://herboloskodrustvo.rs/en/invasive-weeds/

13 List of Invasive Alien Species of Union concern. URL: https://ec.europa.eu/environment/nature/invasivealien/list/index_en.htm.

${ }^{14}$ Milasowszky N., Nowack C., Rabitsch W. Journal for Nature Conservation. 2011. Vol. 19. P. 339-350. 
Ecosystem effects are visible due to primary production, functioning of material and water cycles, soil formation and fertility preservation, as well as production of food, fresh water, fuel, genetic resources, biochemical and pharmaceutical products, folk remedies, ornamental plants, etc. ${ }^{15}$.

In addition, a large number of alien species are plant pathogens or parasites, and invasive weeds and other invasive organisms pose a serious problem to the agricultural, forestry, and fisheries sectors of the economy. Invasive organisms also modify and affect air quality, climate, water cycle (time and intensity of floods, water drainage, etc.), water quality and quantity, disease control, natural pest control, pollination, and erosion control. Due to their impact on the ecosystem, invasive organisms also affect various ecosystem aspects, along with recreation, tourism, spiritual, religious, educational and scientific values of their cultural heritage and others. The economic impact of invasive species in ecosystems is attracting special public attention, which leads to an increase in the cost of measures to control and eradicate invasive species ${ }^{16}$.

Also, certain groups of invasive organisms have a significant impact on human health, either because they directly cause disease and allergies, or are vectors of plant pathogens. A number of invasive species can cause allergic reactions in humans and animals. Problems caused by invasive species can also be mechanical or traumatic ${ }^{17}$.

The vast majority of invasive species - native to North America, rarely East Asian or Mediterranean species, almost half of their composition - members of the family Compositae (Asteraceae).

The list of invasive or plant species of the European Union (approved by resolution 1143/2014) includes the following species: Alternanthera philoxeroides, Asclepias syriaca, Baccharis halimifolia, Cabomba caroliniana, Eichhornia crassipes, Elodea nuttallii, Gunnera tinctoria, Heracleum mantegazzianumm, Heracleum persicum, Heracleum sosnowskyi, Hydrocotyle ranunculoides, Impatiens glandulifera, Lagarosiphon major, Ludwigia grandiflora, Ludwigia peploides, Lysichiton americanus, Microstegium vimineum, Myriophyllum

15 Invasive aquatic species of Europe. Distribution, impacts and management (E. Leppakoski et. al. eds.). 2002. Netherlands : Kluwer Ac. Publ. 583 p.

16 Wratten S.D. Biological control: measures of success. Ed. G. Gurr, S.D. Wratten. Springer, 2002. 429 p.

${ }^{17}$ Invasive weeds. URL: http://herboloskodrustvo.rs/en/invasive-weeds/ 
aquaticum, Myriophyllum heterophyllum, Parthenium hysterophorus, Pennisetum setaceum, Persicaria perfoliata, Pueraria lobata_etc. ${ }^{18}$.

Well-known representatives of invasive plants in Ukraine are: Heracleum sosnowskyi, Solidago canadensis, Acer negúndo, Quercus rubra, Ambrosia artemisiifolia, Asclepias syriaca, Elaeagnus angustifolia etc.

A significant number of scientific publications on the pages of Ukrainian and Polish publications were devoted to prof. Shuvar I.A. ${ }^{19,20,21,22}$, Shuvar I.A., Korpita H. M. ${ }^{23}$, Shuvar I.A., Gudz V.P., Shuvar A.I. ${ }^{24}$, Martyn W., Szuwar I., Martyn J., Szuwar A. ${ }^{25}$ та ін.

В Україні для Закарпатської області 2017 року вперше було складено список інвазивних видів рослин ${ }^{26}$.

Analysis of the state of ecological niches of 50 species of plants, some of which once came from North America to Eurasia, and some from Eurasia to North America, showed that these migrations were not accompanied by changes in their niches (for abiotic factors). This result looks somewhat unexpected against the background of the information boom about the threat of biological invasions.

18 List of Invasive Alien Species of Union concern. URL: https://ec.europa.eu/environment/nature/invasivealien/list/index_en.htm.

${ }^{19}$ Ваточник сирійський (Asclepias syriaca) та його місце у ніші агробіорізноманіття / І.А. Шувар та ін. Сільський господар. 2013. № 1-2. С. 28-32.

${ }^{20}$ Шувар І.А., Корпіта Г.М. Інвазія ячменю мишачого на нові території. Інноваційні технологї в рослинництві : III всеукраїнська наукова Інтернетконференція, м. Камянець-Подільський, 15липня 2020 р. С. 150-152.

21 Шувар I.А. Лаконос американський - нова й маловідома рослина в Україні. Зерно і хліб. 2014. № 3. С. 29-31.

22 Шувар І.А. Після заселення грунту борщівником Сосновського на ньому більше нічого не росте. Зерно і хліб. 2013. № 1. С. 51-55.

23 Шувар І., Корпіта Г., Шувар А. Маловідома рослина-бур'ян інтенсивно поширюється. Сільський господар. 2020. С. 52-55.

24 Шувар І.А., Гудзь В. П., Шувар А.І. Особливо небезпечні рослини України : навчальний посібник / за ред. І.А. Шувар. 2013. 192 с.

25 Waldemar Martyn, Iwan Szuwar, Jarosław Martyn, Anton Szuwar. Bezpieczeństwo ekologiczne Polski i Zachodniej Ukrainy w świetle współczesnych procesów inwazyjnych obcych gatunków roślin (na przykładzie barszczu Sosnowskiego). Międzynarodowa konferencja naukowa pt. „Europa ŚrodkowoWschodnia w procesie. transformacji i integracji. Wymiar bezpieczeństwa" Zamość, 14 -15 maja 2015 roku // Facta Simonidis, 2016. № 1(9). S. 213-229.

26 Перший в Україні офіційний регіональний список інвазійних видів рослин Закарпаття / М.В. Шевера та ін. Вісник НАН України. 2017. № 10. С. 53-61. 
Active invasive species often form large monotonous thickets and displace local plant species, reducing the diversity of animal settlements. These processes are well studied on the example of many invasive species, but the problem, which becomes especially relevant in connection with global warming, etc., has not been studied in the western forest-steppe of Ukraine.

In addition to damage to biodiversity, uncontrolled reproduction of alien species causes direct economic and environmental damage. We know that Acer negundo and Fraxinus pennsylvanica, in addition to the coastal areas of settlement, are actively growing near railway platforms and other track structures. This requires regular felling. Fighting it requires the introduction of additional agronomic measures. Contact with Heracleum sosnowskyi causes photochemical burns, its settlement in river valleys impairs their recreational attractiveness. Calculations of direct material losses from the introduction of alien species - a complex economic problem, approaches to solving which only at the development stage ${ }^{27}$.

Among the invasive species are also dangerous species of the genus Ambrosia. All of them are weeds that are difficult to eradicate, and those that cause significant damage to agriculture, as well as have allergenic properties, and therefore are included in the list of quarantine weeds in many countries ${ }^{28}$.

The adaptive mechanisms of alien invasive weed species are based on two groups of factors: phenotypic plasticity and selection, which leads to the survival of those ecotypes that can adapt to new environmental conditions. Phenotypic plasticity is a phenomenon in which the same genotype can represent a number of different phenotypes in different environmental conditions.

This characteristic becomes apparent as alien weed species adapt to local conditions. In contrast, many researchers studying biological invasions emphasize the importance of conditions for adaptation of invasive species to local environmental conditions in the selection process within intraspecific variability.

27 Invasive aquatic species of Europe. Distribution, impacts and management (E.Leppakoski et. al. eds.). 2002. Netherlands: Kluwer Ac. Publ. 583 p.

${ }^{28}$ Piotrowska K., Kasprzyk I., Brandt J. Long-range transport of Ambrosia pollen to Poland. Agricultural and forest meteorology. 2008. Vol. 148. P. 1402-1411. 
They identified significant genetic variability in local populations of Hypericum perforatum growing in Europe and introduced (foreign) populations, which are quite common as invasive plants in America ${ }^{29}$.

The spread of invasive weeds depends on various factors: species, plant recipients, habitat and climate, as well as socio-economic conditions in the recipient.

Characteristics of the species that are important for the spread of invasive weeds are: the ability of the species to reproduce both by seed and vegetatively, short life cycle, ability of the species to adapt to stressful conditions (phenotypic plasticity) and increased tolerance (plasticity) to environmental changes. However, a number of species differ greatly in the level of invasiveness, although they are characterized by the above properties, while many invasive species have only some of these features ${ }^{30}$.

Scientists believe that the method of reproduction of alien species is decisive in their distribution, which further affects their invasiveness. The formation of large numbers of seeds and the ability to reproduce sexually are often singled out as important qualities for the invasiveness of the species. The distribution of alien species depends not only on the number of seeds produced, but also on its characteristics. In addition, the morphology of the seed coat can be more or less adapted to spraying with different agents ${ }^{31}$.

In particular, the species Erigeron canadensis is mainly spread by wind. Intensive vegetative propagation can also ensure the successful spread of species. As a rule, plants that are propagated vegetatively are more successful invaders than those that are propagated exclusively by seeds. There is a case with the invasive species Fallopia japonica, which spreads very aggressively due to the growth of the rhizome, preventing attempts to eradicate it.

Due to the spread of invasive species, a process is started, which has unpredictable consequences, as a phytocenosis with new properties is formed.

29 Wratten S.D. Biological control: measures of success. Ed. G. Gurr, S.D. Wratten. Springer, 2002. 429 p.

${ }^{30}$ Амброзія полинолиста: ареали, шкодочинність, система захисту / В.С. Циков та ін. 2010.58 с.

${ }^{31}$ Aquatic invasions in the Black, Caspian, and Mediterranean Seas (H. Dumont, T.A. Shiganova, U. Niermann eds.) The Netherlands. Kluver Academic Publishers. 2004. 313 p. 
Experience has shown that such phytocenoses can lead to catastrophic consequences by halting succession at some stage of development, can critically alter biodiversity, lead to the extinction of rare species, or threaten human health with the presence of dangerous organisms.

\section{Scientific aspects of controlling and limiting the invasion of rare weeds species}

An important aspect in the study of biological invasions is the clarification of terms and simplification of definitions. It is very important to emphasize that organisms can be divided into relatives and alients by their origin. Relatives are species that grow in areas that are part of their natural range, and alients organisms are those that have been introduced into an area that is not part of their natural range. There are also species that cannot be reliably assigned to one of these categories, and they are called cryptogenic species. Alients species in the area where they were introduced can threaten the survival of native species and adversely affect ecosystems, agriculture, human and domestic health, and the socio-economic aspects of the state.

Determining biological invasions by the criterion of their impact on the group implies that the species must have a significant (positive or negative) impact on it, ie the ecosystem in which it spreads, so that it can be considered invasive. In general, this impact depends on the biological characteristics of the species and the ecosystem in which the species is introduced.

The introduction and spread of the species in new territories began during the tribal movements and due to the rapid disturbance of natural areas it intensified with the development of civilization, social, industrial and urban development, followed by rapid progress in technology development, modernization of transport logistics and transport flows, especially transoceanic and intercontinental, so that the number of intentionally or accidentally introduced species is growing rapidly.

However, despite numerous studies, it is not possible to find common differences between invasive species and nearby plants that have not shown the ability to do so. This significantly limits the ability to predict the rate of settlement of new species. Almost the only way to predict is to analyze the settlement of invasive species in neighboring areas. If the 
species shows invasive activity in any neighboring areas, it is worth expecting the expansion of its range ${ }^{32}$.

For a large number of alien weed species, the exact time and route of introduction are unknown, and the method of their spread is only an assumption. Researchers are trying to diagnose penetration routes and distribution corridors for specific regions. One of the approaches to the study of this problem involves the analysis of museum collections, which are a rich source of information, in particular, for herbologists, ecologists, phytogeographers ${ }^{33}$.

Researchers generally agree that some natural processes can never be explained and described without the use of these collections of animals and herbariums of cultivated plants and weeds. Biological collections are important for monitoring the extinction of certain species and the disturbance of ecosystem biodiversity due to anthropogenic impact. Herbarium collections very clearly document and confirm the presence or absence of the species, thus enabling a fairly reliable reconstruction of the process of spreading invasive species. Maps (diagrams) based on the analysis of available herbarium materials show the spatial distribution of «winning plants» depending on the period of time and confirm the probability of invasion routes and directions of their spread, as well as speed, ie dynamics of distribution of alien invasive species.

Some authors believe that the difference should also be made in terms of detection time. Accordingly, introduced alien species can be divided into: archaeophytes - species that were introduced to Europe before 1492 (discovery of America) and neophytes - species introduced after this period of time.

There is also an even more detailed division of adventive species according to the time of their introduction: archeophytes - introduced between the Paleozoic and Neolithic periods; paleophytes - introduced in ancient times and the Middle Ages before the discovery of America (1492); neophytes - introduced after the discovery of America and

${ }^{32}$ Pheloung P.C., Williams P.A., Halloy S.R. A weed risk assessment mode for use as a biosecurity tool evaluating plant introductions. Journal of Environmental Management. 1999. Vol. 57. P. 239-251.

${ }^{33}$ Firsov G.A., Buligin N.E., Thögersen C.G. A comparision of the assortment of broad-leaved trees and shrubs used in City Planting in NW. Russia and NE. Sweden. Röbäcksdalen meddelar. Umeå. 1994. № 2. 25 P. 
before World War II, and neotophytes - introduced from the beginning of World War II and to this day ${ }^{34}$.

Since the general pattern for the evolution of phytocenoses by invasion has not yet been deduced, each case must be considered separately. Not all ecosystems are equally vulnerable to invasions. In the early stages, ecosystems are more vulnerable to the invasion of alien species.

In the later stages of succession, in forest ecosystems, the formation of econish is compacted, and the specialization of species is narrowed, which also complicates the invasion. Invasions occur here but not so often. Their main reason is anthropic spontaneous or purposeful transfer of species. Transformer species are determined by the ability to radically change the ecosystem into which they penetrate.

Detailed analysis of the problem and generalization of the still insufficient amount of processed experimental material indicates the importance of effective control of invasive plant species at an early stage of its detection ${ }^{35,36}$. The best control option depends on a number of factors, including knowledge of the potential weed damage, the relative numbers of plant species, site characteristics, the cost of the control method, the environmental impact of the weeds, and the method of control.

Methods of control of invasive plant species can be classified into three categories: physical (mechanical), chemical and biological. Physical control involves the manual removal of part or all of the plant (eg, felling, cutting, mowing, etc.); chemical control includes spraying with herbicides; biological control involves the release of specially introduced natural enemies (eg, fungal pathogens and insects) that reduce the strength of plants or the formation of seeds.

Integrated monitoring is often required, which usually involves a combination of at least two of these methods.

Physical and chemical control methods are usually short-term and relevant for smaller plant infestations, which can lead to the complete destruction of invasive species if repeated follow-up is carried out. Biological control is much more relevant for large-scale invasions and

${ }^{34}$ Preventing the Spread of Invasive Plants: URL: https://www.calipc.org/docs/ bmps/dd9jwo1ml8vttq9527zjhek99qr/BMPLandManager.pdf

35 Шувар І.А., Корпіта Г.М. Особливості забур'янення агроценозів ячменю ярого і картоплі залежно від застосування гербіцидів. ScienceRise. 2016. № 9(1). C. $39-43$.

36 Еколого-гербологічний моніторинг і прогноз в агроценозах / I.А. Шувар та ін. 2011.208 c. 
aims to control (rather than eradicate) plants where other methods are not appropriate $^{37}$.

The choice of method of control of invasive species has some interesting differences depending on the form of plant life. Physical and chemical methods are usually most commonly used to control herbaceous plants, including hemicryptophytes (biennials and perennials), therophytes (annuals), and cryptophytes (in which regeneration buds are laid on rhizomes). The biological method is used mainly to control hemicryptophytes, phanerophytes (tree species) and nanophanerophytes (tree bushes). Prevention, early detection and destruction of weed species is the most cost-effective and effective means of invasive plant management. It is important to make sure that new weeds or parts of the vegetative reproductive organs of plants are not introduced into the new territory ${ }^{38,39}$.

The spread of invasive plants occurs in the following ways:

- Contaminated seeds, feed grain, hay, straw, mulch;

- Movement of contaminated equipment and vehicles in clean areas;

- Livestock and wildlife;

- Scattering of gravel on roads containing seeds;

- Rest and recreation;

- Water and wind transfers;

- Freight rail transport.

Once invasive weed species are detected, it is important to take precautions to prevent them from spreading to clean areas.

This includes managing activities in meadows and pastures to maintain healthy plant communities, and clearing litter as soon as possible.

Among the main measures to prevent the spread of invasive plants are the following:

- Vehicles and equipment must be clean of invasive plants and seeds;

- Minimization of soil disturbance during all construction and maintenance works;

37 Invasive aquatic species of Europe. Distribution, impacts and management (E. Leppakoski et. al. eds.). 2002. Netherlands : Kluwer Ac. Publ. 583 p.

38 Еколого-гербологічний моніторинг і прогноз в агроценозах / I.А. Шувар та ін. 2011. 208 c.

393 Invasive species. URL: http://stateoftheworldsplants.org/2017/report/ SOTWP_2017_9_invasive_species.pdf 
- Promoting the creation of a community of health plants;

- Restriction of movement of soil or gravel littered with weeds;

- Use of certified seed mixtures that do not contain weeds;

- Elimination of locations - neutralization of existing invasive groups of plants and control of new ones;

- Maintenance and restriction of movement of invasive plants from neighboring lands or administrative territories;

- Motorways, railways and waterways are often corridors that need to be controlled to limit the spread of invasive plants;

- Protection of areas free from invasive plants;

- Providing information to the general public about limited weeds;

- Keeping machinery and vehicles clean ${ }^{40}$.

The main feature of European and world policy on invasive species is the direction of knowledge, efforts and funds for the enrichment and protection of biological diversity. It is defined by the UN Convention on Biological Diversity, 1992 and ratified in Ukraine in 1994.

The issue of biodiversity protection is under the auspices of the Convention on the Conservation of European Wildlife and Natural Habitats, 1979 (Berne Convention), ratified in Ukraine in 1999. It provides for the prevention of invasions, control or destruction of invasive alien species considered in the framework of the implementation of the Berne Convention by its Standing Committee ${ }^{41}$.

Control of invasive alien plant species in Ukraine involves the introduction of European practices for the protection of biological diversity: Ukraine's adoption of European rules aimed at improving the management of alien species in protected areas, the introduction of Codes of Conduct with invasive alien species for botanical gardens and arboretums conservation of natural biodiversity ${ }^{42}$.

The generalization of the scientific community shows that the spread of invasive species of weeds is the result of high morpho-biological adaptation to soil and climatic conditions, miscalculations in the production activities of landowners, as well as weak material and technical base of most farms, lack of state target program.

${ }^{40}$ Invasive weeds. URL: http://herboloskodrustvo.rs/en/invasive-weeds/

41 The Problem With Invasive Plants. URL: https://www.portlandoregon.gov/ bes/article/330681

42 Preventing the Spread of Invasive Plants: URL:https://www.calipc.org/docs/ bmps/dd9jwo1ml8vttq9527zjhek99qr/BMPLandManager.pdf 
The isolation of this group of invasive weeds was due to the plowing of chernozems or by bringing their seeds from other regions or remote parts of the world in the process of increasing trade between different countries.

Therefore, to protect crops, as well as agricultural land for other purposes from the most harmful segetal weeds, landowners must adhere to a regulated set of measures aimed at preventing their re-emergence, fruiting and regeneration ${ }^{43}$.

The protection of useful biodiversity of flora and fauna of a particular area, region or even a certain soil and climatic zone is the main and most important task of sustainable functioning of agro-industrial production and successful solution of urgent problems of agricultural ecology. In order to effectively function the important components of the agroecosystem, it is necessary to pay special attention to the study of the taxonomy of species of adventive plants, their participation in habitats, population characteristics, etc.

The results of such work will reveal the peculiarities of the formation and role of adaptive capacity of species of this group - on the one hand, and on the other - will contribute to the development of measures and means of prevention and reliable assessment of environmental risks and threats to mitigate the effects of invasive alien species. groups and ecosystems, as well as for the welfare of the population.

\section{CONCLUSIONS}

In recent decades, the problem of invasion of rare plant species, including weeds, has become increasingly threatening. Invasive plant species compete so successfully with other plants that they can displace them, creating a monoculture that inhibits and levels the growth of other plant species. Invasive plant species, including weeds, can upset the balance of an ecosystem. They are often larger, faster growing or more aggressive than native species, and can occupy the habitat where they grow. Invasive species harm the environment, the state's economy and human health.

Habitat loss and invasive plants are a major cause of natural biodiversity loss. Invasive plant species spread rapidly and can displace local plant communities, prevent the growth of indigenous plants and create the conditions for monoculture. Healthy vegetation is rich in a variety of grasses, shrubs and trees that grow in symbiosis, while invasive plants cause biological pollution, reducing the diversity of plant species.

\footnotetext{
${ }^{43}$ Invasive weeds. URL: http://herboloskodrustvo.rs/en/invasive-weeds/
} 
To achieve a significant result in the implementation of this problem, it is necessary to combine all possible measures and methods of combating invasive species, as well as to involve the general public to curb their spread. In addition, there is an urgent need to create a special department of the quarantine inspection service, which will not only identify the foci of the invasion, but also attract and organize the relevant specialized units to destroy them.

Activation of invasion processes makes it necessary to monitor and search for ways to localize or eliminate the formed foci of invasion. Therefore, it is important to perform research to determine the number of invasive species.

Important for the control of invasive species are:

- monitoring, accumulation, grouping and analysis of information on invasive species in the economy, district, region;

- perform research to assess the risks of specific invasive species;

- develop and recommend measures to prevent their penetration and spread;

- develop and recommend measures to eradicate and / or control already introduced species;

- exchange of information on invasive species through scientific publications, databases, reports of experts at conferences of various levels.

\section{SUMMARY}

As a result of active global economic trade and travel around the world between regions that were once isolated from each other, the number of exotic species being introduced is increasing.

Without natural predators, invasive species are able to reproduce and cause significant environmental and economic damage where they have invaded.

Invasive species can defeat native species, suppress native plants and trees, destroy habitat, and exceed the density of native species in a given area, potentially upsetting the entire ecosystem. They can threaten the biodiversity of an ecosystem, especially if they suppress local species or completely provoke their extinction and cause significant economic damage to local communities in their new environment.

As the global environment is damaged and developed around the world, disturbed ecosystems are becoming increasingly vulnerable to the invasion of invasive species. In disturbed ecosystems, introduced 
invasive species can take advantage of open niches that were previously occupied by local species.

It is important to know and be able to detect invasive species in time, which first enters the new territory, there will be a chance to eradicate it due to the rapid response to take measures of influence. If eradication is not possible, then the species may be subject to control and management. When deciding on what measures to effectively implement their destruction, it is necessary to adhere to objective monitoring and comprehensive control of such plant objects.

\section{References}

1. Гербологічний атлас-довідник України / I.A. Шувар та ін. 2020. $388 \mathrm{c}$.

2. Землеробство : підручник / В.П. Гудзь ; за ред. В.П. Гудзя. 2014. 492 c.

3. Іващенко О.О. Бур'яни в агрофітоценозах. 2001. 236 с.

4. Конопля M.I., Курдюкова О.М., Мельник Н.О. Забур'яненість агрофітоценозів як екологічна проблема землеробства. Фальифейнівські читання : міжнар. наук.-практ. конф., 21-23 травня 2009 р. Херсон, 2009. С. 157-161.

5. Українсько-російсько-англійський тлумачний словник із загального землеробства / за ред. В.П. Гудзя та ін. 2017. 392 с.

6. Амброзія полинолиста: ареали, шкодочинність, система захисту / В.С. Циков та ін. 2010. 58 с.

7. Перший в Україні офіційний регіональний список інвазійних видів рослин Закарпаття / М.В. Шевера та ін. Вісник НАН Украӥни. 2017. № 10. C. 53-61.

8. Шувар I.A. Лаконос американський - нова й маловідома рослина в Україні. Зерно і хліб. 2014. № 3. С. 29-31.

9. Шувар I.А. Лаконос американський: бур'ян, чи корисна рослина? Агробізнес сьогодні. 2013. № 22(269). С. 24-27.

10.Шувар I.А. Після заселення грунту борщівником Сосновського на ньому більше нічого не росте. Зерно $і$ хліб. 2013. № 1. C. 51-55.

11.Борщівник Сосновського: користь, чи шкода? / I.А. Шувар та ін. Сільський господар. 2011. № 11-12. С. 22-30.

12.Еколого-гербологічний моніторинг і прогноз в агроценозах / I.А. Шувар та ін. 2011. 208 с.

13.Шувар I.A., Корпіта Г.М. Вплив елементів технології вирощування на забур'яненість та продуктивність ячменю ярого 
і картоплі. Збірник наукових пращь наиіонального наукового центру «Інститут землеробства НААН», 2016. № 3-4. С. 71-81.

14. Інвазія золотушника канадського (Solidago Canadensis L.) на теренах Західного Лісостепу України і Польщі / I.A. Шувар та ін. Роль науково-технічного забезпечення розвитку агропромислового комплексу в сучасних ринкових умовах : матеріали Всеукраїнської науково-практичної конференції, 25 лютого 2021 р. Дніпро. 2021. C. 326-328.

15. Шувар І.А., Корпіта Г.М., Юник А.В. Продуктивність ячменю ярого та картоплі в агроценозах західного Лісостепу України : монографія. Львів : Українські технології, 2019. 152 с.

16. Ваточник сирійський (Asclepias syriaca) та його місце у ніші агробіорізноманіття / I.А. Шувар та ін. Сільський господар. 2013. № $1-2$. C. $28-32$.

17.Новий поселенець біорізноманіття України - лаконос американський / I.А. Шувар та ін. Сільський господар. 2014. №.7-8. C. $20-24$.

18. Шувар I., Корпіта Г., Шувар А. Маловідома рослина-бур'ян інтенсивно поширюється. Сільський господар. 2020. С. 52-55.

19. Шувар I.A. Екологічні основи зниження забур'яненості агрофітоценозів. 2000, 2008. 496 с.

20.Шувар I.А., Гудзь В.П., Шувар А.І. Особливо небезпечні рослини України : навчльний посібник / за ред. I.А. Шувар. 2013. $192 \mathrm{c}$.

21.Шувар I.А., Корпіта Г.М. Бур'ян чина бульбиста мігрує українськими вгіддями. Агробізнес сьогодні. 2020. № 17(432). C. $58-59$.

22. Шувар I.А., Корпіта Г.М. Особливості впливу забур'яненості посівів на продуктивність агрофітоценозу в сучасному землеробстві України. Теоретичні основи $і$ практичні аспекти використання ресурсоощадних технологій для підвищення ефективності агропромислового виробництва і розвитку сільських територій : матеріали XV Міжнар. наук.-практ. форуму, 24-26 вересня 2014 р. Львів, 2014. С. 40-42.

23. Шувар I.А., Корпіта Г.М. Інвазія ячменю мишачого на нові території. Інноваційні технології в рослинництві : III всеукраїнська наукова Інтернет-конференція, м. Кам'янець-Подільський, 15 липня 2020 p. C. $150-152$.

24.Шувар I.A., Корпіта Г.М. Особливості забур'янення агроценозів ячменю ярого і картоплі залежно від застосування гербіцидів. ScienceRise. 2016. № 9(1). C. 39-43. 
25. Aquatic invasions in the Black, Caspian, and Mediterranean Seas (H. Dumont, T.A. Shiganova, U. Niermann eds.) The Netherlands. Kluver Academic Publishers, 2004. 313 p.

26.City of Portland Invasive Plant Management Strategy Report. URL: http://www.portlandonline.com/bes/index.cfm?c=47815\&

27. Control Invasive Plants. URL: https://www.coastalisc.com/ how-to-control-invasive-plants/

28.Dgebuadze Yu.Yu., Feniova I.Yu. Stochastic and deterministic mechanisms structuring aquatic communities invaded by alien species. Biological Invasions: Towards a Synthesis. NEOBIOTA. V. 8 (2009): 61-74.

29. Firsov G.A., Buligin N.E., Thögersen C.G. A comparision of the assortment of broad-leaved trees and shrubs used in City Planting in NW. Russia and NE. Sweden. Röbäcksdalen meddelar. Umeå, 1994. № 2. P. 25.

30. Invasive aquatic species of Europe. Distribution, impacts and management (E.Leppakoski et. al. eds.). 2002. Netherlands: Kluwer Ac. Publ. 583 p.

31.Invasive species. URL: http://stateoftheworldsplants.org/ 2017/report/SOTWP_2017_9_invasive_species.pdf

32.Invasive weeds. URL: http://herboloskodrustvo.rs/en/invasiveweeds/

33.List of Invasive Alien Species of Union concern. URL: https://ec.europa.eu/environment/nature/invasivealien/list/index_en.htm

34. Martyn W., Szuwar I., Martyn J., Szuwar A. Bezpieczenstwo ekologiczne Polski i Zachodniej Ukrainy w swietle wspolczesnych procesow inwazyjnych obcych gatunkow roslin (na przykladzie barszczu Sosnowskiego). Mi?dzynarodowa konferencja naukowa pt. „Europa Srodkowo-Wschodnia $\mathrm{w}$ procesie transformacji i integracji. Wymiar bezpieczenstwa". Zamosc, 14-15 maja 2015 roku. Facta Simonidis. 2016. NR 1 (9). S. 213-229.

35. Milasowszky N., Nowack C., Rabitsch W. Journal for Nature Conservation. 2011. Vol. 19. P. 339-350.

36. Notov A.A., Vinogradova Yu.K., Mayorov S.R. On the problem of development and management of regional black books. Russian Journal of Biological Invasions. 2011. Vol. 2. № 1. P. 35-45.

37.Pheloung P.C., Williams P.A., Halloy S.R. A weed risk assessment mode for use as a biosecurity tool evaluating plant introductions. Journal of Environmental Management. 1999. Vol. 57. P. 239-251. 
38. Piotrowska K., Kasprzyk I., Brandt J. Long-range transport of Ambrosia pollen to Poland. Agricultural and forest meteorology. 2008. Vol. 148. P. 1402-1411.

39. Preventing the Spread of Invasive Plants. URL: https://www.calipc.org/docs/bmps/dd9jwo1ml8vttq9527zjhek99qr/BMP LandManager.pdf

40. Shuvar I., Snitynsky V., Hudz V., Shuvar A. Ekologiczne problemy rolnictwa $\mathrm{w}$ warunkach współczesnych zmian klimatycznych na Ukrainie i na świecie. VII Międzynarodowe Sympozjum Naukowe nt. Klimat pola uprawnego Meteorologia i klimatologia w służbie rolnictwa i turystyki. Zamość-Łuck, 27-29 Września, 2012 r. S. 40.

41. The Problem With Invasive Plants. URL: https://www.portlandoregon.gov/bes/article/330681

42. Waldemar Martyn, Iwan Szuwar, Jarosław Martyn, Anton Szuwar. Bezpieczeństwo ekologiczne Polski i Zachodniej Ukrainy w świetle współczesnych procesów inwazyjnych obcych gatunków roślin (na przykładzie barszczu Sosnowskiego). Międzynarodowa konferencja naukowa pt. „Europa Środkowo-Wschodnia w procesie. transformacji i integracji. Wymiar bezpieczeństwa" Zamość, 14 -15 maja 2015 roku // Facta Simonidis, 2016. № 1(9). S. 213-229.

\section{Information about the authors: Shuvar Ivan Antonovych,} Doctor of Agricultural Sciences, Professor, Honored Worker of Science and Technology of Ukraine, Professor at the Department of Plant Technologies of the Faculty of Agrotechnologies and Ecology

Lviv National Agrarian University 1, V. Velykoho str., Dublyany, Lviv region, 80381, Ukraine

Korpita Hanna Mykhaylivna,

Candidate of Agricultural Sciences, Senior Lecturer at the Department of Genetics, Selection and Plant Protection of the Faculty of Agrotechnologies and Ecology Lviv National Agrarian University 1, V. Velykoho str., Dublyany, Lviv region, 80381, Ukraine 